\title{
Biphasic Alteration of the Inhibitory Synapse Scaffold Protein Gephyrin in Early and Late Stages of an Alzheimer Disease Model
}

\author{
Eva Kiss, ${ }^{\star \dagger}$ Karin Gorgas, ${ }^{*}$ Andrea Schlicksupp, ${ }^{*}$ Dagmar Groß, ${ }^{\ddagger}$ Stefan Kins, ${ }^{\ddagger}$ Joachim Kirsch, ${ }^{*}$ and Jochen Kuhse*
}

\begin{abstract}
From the Institute of Anatomy and Cell Biology, ${ }^{*}$ University of Heidelberg, Heidelberg, Germany; the Department of Cellular and Molecular Biology, ${ }^{\dagger}$ University of Medicine and Pharmacy of Târgu Mures, Târgu Mures, Romania; and the Department of Human Biology and Human Genetics, ${ }^{\ddagger}$ University of Kaiserslautern, Kaiserslautern, Germany
\end{abstract}

\author{
Accepted for publication \\ May 10, 2016. \\ Address correspondence to Eva \\ Kiss, M.D., Department of \\ Cellular and Molecular Biology, \\ University of Medicine Târgu \\ Mures, Str. Gheorghe Marinescu \\ 38, 540139 Târgu Mureş, \\ Romania; or Jochen Kuhse, \\ Ph.D., Institute of Anatomy and \\ Cell Biology, University of \\ Heidelberg, Im Neuenheimer \\ Feld 307, 69120 Heidelberg, \\ Germany. E-mail: kiss@ana. \\ uni-heidelberg.de or jochen. \\ kuhse@urz.uni-heidelberg.de.
}

\begin{abstract}
The pathogenesis of Alzheimer disease (AD) is thought to begin many years before the diagnosis of dementia. Accumulating evidence indicates the involvement of GABAergic neurotransmission in the physiopathology of AD. However, in comparison to excitatory synapses, the structural and functional alterations of inhibitory synapses in $A D$ are less well characterized. We studied the expression and distribution of proteins specific for inhibitory synapses in hippocampal areas of APPPS1 mice at different ages. Interestingly, by immunoblotting and confocal fluorescence microscopy, we disclosed a robust increase in the expression of gephyrin, an organizer of ligand-gated ion channels at inhibitory synapses in hippocampus CA1 and dentate gyrus of young presymptomatic APPPS1 mice (1 to 3 months) as compared to controls. The postsynaptic $\gamma 2-\mathrm{GABA}(\mathrm{A})$-receptor subunit and the presynaptic vesicular inhibitory amino acid transporter protein showed similar expression patterns. In contrast, adult transgenic animals (12 months) displayed decreased levels of these proteins in comparison to wild type in hippocampus areas devoid of amyloid plaques. Within most plaques, strong gephyrin immunoreactivity was detected, partially colocalizing with vesicular amino acid transporter and GABA(A)-receptor $\gamma 2$ subunit immunoreactivities. Our results indicate a biphasic alteration in expression of hippocampal inhibitory synapse components in AD. Altered inhibition of neurotransmission might be an early prognostic marker and might even be involved in the pathogenesis of AD. (Am J Pathol 2016, 186: 2279-2291; http://dx.doi.org/10.1016/j.ajpath.2016.05.013)
\end{abstract}

Alzheimer disease (AD) is the most prevalent form of dementia, characterized by progressive loss of memory and cognitive capacities. ${ }^{1}$ Neuropathological findings include extracellular deposits of $\beta$ amyloid protein $(A \beta)$ in plaques, and intracellular deposits of hyperphosphorylated tau protein in neurofibrillary tangles. ${ }^{2}$ Mutations in amyloid precursor protein (APP) as well as in presenilin 1 and presenilin 2 genes were identified as causes of autosomal dominant, early-onset familial AD. ${ }^{3}$ These mutations lead to increased levels of $\mathrm{A} \beta$, the main component of extracellular plaques in AD, a common finding in both familial and sporadic AD. Despite enormous research efforts, the neurobiological processes that cause sporadic $\mathrm{AD}(90 \%$ to $95 \%$ of $\mathrm{AD}$ cases) are not completely understood. Attention has been focused on the pathogenic mechanisms that relate $A \beta$ plaque and neurofibrillary tangle pathology to cognitive symptoms, but more recently increasing evidence identified early synaptic changes, which precede plaque and tangle formation, as the more probable initiators of cognitive impairment. ${ }^{4,5}$ Most studies focused on the loss of plasticity and functions of excitatory synapses in $\mathrm{AD} .^{6-8} \mathrm{~A}$ possible contribution of structural and functional impairment of inhibitory synapses in AD pathogenesis is less well characterized. Postmortem studies suggest that $\gamma$-aminobutyric acid receptor $\left(\mathrm{GABA}_{\mathrm{A}} \mathrm{R}\right)$ expression is decreased in cortical areas of $\mathrm{AD}$ patients. ${ }^{9-11}$

\footnotetext{
Supported by the Stiftung Rheinland-Pfalz für Innovation and by departmental funding from the Department of Anatomy and Cell Biology of the University of Heidelberg.

Disclosures: None declared.
} 
Furthermore, loss of functional $\mathrm{GABA}_{\mathrm{A}} \mathrm{Rs}$ in $\mathrm{AD}$ brain was observed. ${ }^{12}$ Alterations of inhibition and disinhibition were shown to result in hyperexcitability and desynchronization of neuronal circuits, ${ }^{13,14}$ and thus impairment of learning and information processing in neocortical circuits. ${ }^{15}$ In this context, understanding of inhibition in $\mathrm{AD}$ pathogenesis appears to be crucially important.

At inhibitory synapses, the postsynaptic scaffold protein gephyrin was shown to be important for clustering glycine receptors and different types of $\mathrm{GABA}_{\mathrm{A}} \mathrm{Rs}$ at postsynaptic membrane specializations. ${ }^{16-19}$ These pentameric receptor complexes open intrinsic $\mathrm{Cl}^{-} / \mathrm{HCO}^{-}$ion channels on ligand binding, resulting in hyperpolarization of the postsynaptic membrane of adult neurons, thus antagonizing excitatory, glutamate gated sodium/calcium channels. ${ }^{20}$ The scaffold function of gephyrin might be comparable to the function of postsynaptic density protein 95 (PSD95) and other nonhomologous scaffold proteins at excitatory synapses. ${ }^{21}$

Gephyrin is a microtubule and dynein light chain binding protein transported along microtubule tracks and was proposed to be anchored to microtubules at postsynaptic membrane specializations. ${ }^{22-24}$ Moreover, glycogen synthase kinase $3 \beta$ and cyclin-dependent kinase 5 have been shown to phosphorylate gephyrin, resulting in structural alterations of synaptic gephyrin clusters, inhibitory transmission, and changes of gephyrin protein levels. ${ }^{25-28}$ Deregulation of cyclindependent kinase 5 and glycogen synthase kinase $3 \beta$ enzyme activities has pivotal, pleiotropic effects in $\mathrm{AD}$ pathology ${ }^{29}$ (eg, causing hyperphosphorylation of tau and thus functional impairment of microtubules, a process that is thought to contribute to $\mathrm{AD}$ pathology). ${ }^{30}$ Therefore, impaired microtubules and altered cyclin-dependent kinase 5 and glycogen synthase kinase $3 \beta$ activity might effect gephyrin and thus inhibitory functions in the central nervous system.

Herein, we analyzed the levels of gephyrin phosphorylation at Ser270 and total protein levels in APPPS1 mice at different age stages. Unexpectedly, by immunoblotting and immunohistochemistry, we found a robust increase in the expression of gephyrin in the hippocampus of presymptomatic age stages of APPPS1 mice, which correlated with an increased expression of postsynaptic $\gamma 2-\mathrm{GABA}_{\mathrm{A}}$ receptor subunits and presynaptic vesicular amino acid transporter (VIAAT) protein, whereas in later stages gephyrin and $\gamma 2-G_{A B A} R$ subunits were reduced; thus, our data are in agreement with the hypothesis that altered inhibitory input might be involved in the pathogenesis of AD.

\section{Materials and Methods}

\section{Animals}

APPPS1 mice were obtained from Prof. M. Jucker (German Center for Neurodegenerative Diseases, Tübingen, Germany) and bred in the animal unit of the University of Kaiserslautern (Kaiserslautern, Germany). Offspring were genotyped as described previously. ${ }^{31}$ Male APPPS1 mice and age-matched nontransgenic control mice [wild type (WT)] of the same genetic background (C57BL/6) were used for analysis. The double-transgenic APPPS1 mice coexpress KM670/671NL Swedish mutated APP and L166P-mutated presenilin 1 under the control of a neuron-specific Thy 1 promoter element with a threefold overexpression of human APP over endogenous mouse APP. In this transgenic mouse model, amyloid plaque deposition appears in the dentate gyrus at 2 to 3 months of age and in the CA1 region of the hippocampus at approximately 4 to 5 months of age. ${ }^{32}$ Global neuronal loss is not observed in APPPS1 mice. Modest neuron loss is found in some brain subregions first at older ages (eg, 17 months). ${ }^{33}$

\section{Tissue Preparation}

The 1-, 3-, 8-, and 12-month-old APPPS1 and WT mice ( $n=4$ to 6 animals per group) were deeply anesthetized with isoflurane and decapitated, and brains were prepared. Brain hemispheres were separated, and the cerebellum was removed. For immunohistochemistry, one hemisphere of each brain was mounted in optimal cutting temperature embedding compound (VWR Chemicals, Leuven, Belgium) and snap frozen on $100 \%$ alcohol-dry ice mixture. For biochemical analysis, the hippocampus of the other hemisphere was isolated and immediately frozen in liquid nitrogen. Tissue samples were stored at $-80^{\circ} \mathrm{C}$ until use.

This study was performed in accordance with the European Communities Council Directive (86/609/EEC) to minimize animal pain or discomfort. The local animal care and use committee (Interfakultäre Biomedizinische Forschungseinrichtung, INF347, 69120 Heidelberg) gave approval for the study under the number T-65/15.

\section{Protein Extracts and Immunoblot Analysis}

Frozen hippocampus was homogenized in $350 \mu \mathrm{L}$ ice-cold lysis buffer: $50 \mathrm{mmol} / \mathrm{L}$ Tris- $\mathrm{HCl}$, pH 7.5, $150 \mathrm{mmol} / \mathrm{L} \mathrm{NaCl}$, $1 \%$ (v/v) nonyl phenoxylpoly-ethoxylethanol (NP40), 0.25\% (w/v) SDS, $2 \mathrm{mmol} / \mathrm{L}$ Na-orthovanadate, and protease inhibitor cocktail (cOmplete; Roche, Basel, Switzerland) using Precellys homogenization tubes (91-PCS-CK14S) with two intervals of maximal shaking intensities (60 seconds) each in a tissue mixer mill MM301 (Retsch, Utrecht, the Netherlands). Extracts were passed through a cannula $(0.4 \times 19 \mathrm{~mm})(10 \times$ fold) before total lysates were used for protein determination using a BCA-assay kit (Thermo Fisher, Waltham, MA). Total protein extracts $(30 \mu \mathrm{g})$ were adjusted to $1 \times$ Laemmli-loading buffer conditions (2\% SDS, $10 \%$ glycerol, 5\% 2mercaptoethanol, $0.002 \%$ bromphenol blue, and $0.06 \mathrm{~mol} / \mathrm{L}$ Tris- $\mathrm{HCl}, \mathrm{pH} 6.8$ ), heated to $95^{\circ} \mathrm{C}$ for $5^{\prime}$, loaded onto $12.5 \%$ polyacrylamide-SDS gels, and separated with constant voltage. Proteins were blotted on polyvinylidene difluoride membranes (Merck Millipore, Darmstadt, Germany), according to the manufacturer's instructions. Membranes were probed with three different antibodies against gephyrin (Table 1): mouse phospho-specific monoclonal anti-gephyrin 
antibody mAb7a (p-Geph, 1:500), rabbit anti-gephyrin antibody (Geph1, 1:1000), rabbit anti-gephyrin antibody Ab-175 (Geph2, 1:500), as well as with mouse anti-PSD95 antibody (1:500) (BD Transduction Laboratories, San Jose, CA; $610495)$ and mouse anti- $\beta$-actin antibody (1:20000) (Abcam, Cambridge, UK; AC-15, ab6276). The corresponding horseradish peroxidase-conjugated secondary antibodies (Bio-Rad, Hercules, CA) were detected using ECL Prime detection kit (Amersham Biosciences, Amersham, UK). After exposure to hyperfilms (Amersham Biosciences), pixel intensities of the bands of interest were analyzed using ImageJ (NIH, Bethesda, MD). Immunoreactive band intensities were normalized to the corresponding signals revealed by anti- $\beta$-actin antibodies and averaged for each individual animal hippocampal extract from four identical replicates of immunoblots.

\section{Immunolabeling}

Coronal cryostat sections ( $8 \mu \mathrm{m}$ thick) cut from fresh-frozen brains were mounted on SuperFrost Plus slides (Menzel $\mathrm{GmbH}$, Braunschweig, Germany) and stored at $-20^{\circ} \mathrm{C}$. They were then thawed, fixed with methanol for 10 minutes at $4^{\circ} \mathrm{C}$, and preincubated for 20 minutes at $95^{\circ} \mathrm{C}$ in sodium citrate buffer (10 mmol/L, 0.05\% Tween-20, pH 6.0) for antigen retrieval. After three rinses in phosphate-buffered saline (pH 7.4) and preincubation in blocking solution (5\% normal horse serum, 5\% bovine serum albumin) for 60 minutes, sections were incubated overnight with primary antibodies diluted in blocking solution. For detection of gephyrin, the same three primary antibodies were used as for immunoblotting (Table 1): pGeph, 1:500; Geph1, 1:500; and Geph2, 1:100. The antibodies were applied separately or in combination with either polyclonal rabbit anti-VIAAT antibody (1:500; Synaptic Systems), polyclonal goat antiVGAT antibody (D-18) (1:50, Santa Cruz Biotechnology, Dallas, TX), or guinea pig antisera against the $\mathrm{GABA}_{\mathrm{A}}$-receptor subunit $\gamma 2$ (1:400, Synaptic Systems, Göttingen, Germany) and for some sections with monoclonal mouse anti-microtuble-associated protein 2 (MAP-2) antibody (Chemicon, Darmstadt, Germany, 1:100), and anti-amyloid$\beta$ antibody, clone W02 (1:500, Merck Millipore). The sections were rinsed and incubated for 60 minutes at room temperature with corresponding secondary antibodies coupled with indocarbocyanine (Cy2, 1:200), Сy3 (1:500) diluted in blocking buffer. DAPI was used to visualize nuclei. To reduce autofluorescence, mainly caused by accumulation of lipofuscin granules, tissue samples were treated with Autofluorescence Eliminator Reagent (Merck Millipore), according to the manufacturer's recommendations. Finally, sections were rinsed and mounted with Mounting Medium Mowiol/Dabco (Roth, Karlsruhe, Germany). Controls omitting the primary antibodies were included. Serial sections from APPPS1 and WT mice were assayed simultaneously using the same batches of solutions to minimize variability in immunolabeling conditions.

\section{Confocal Laser Scanning Microscopy and Quantitative Immunofluorescence Analysis}

Confocal microscopy was performed with a Leica TCS SP8 microscope (Leica Microsystems CMS GmbH, Mannheim, Germany) using a HC PL APO CS2 $63.0 \times 1.40$ oil objective. The emission filter settings were 490 to $540 \mathrm{~nm}$ for PMT2 (green) and 555 to $620 \mathrm{~nm}$ for PMT3 (red). The images were acquired in sequential mode with a frame average of 4 . Stacks of 10 optical images $(1024 \times 1024$ pixels $)$ spaced by $400 \mathrm{~nm}$ were recorded. Three different areas in each hippocampus (five randomly chosen fields of the CA1 region-pyramidal cell layer and stratum radiatum - and three randomly chosen fields of the dentate gyrus per brain; $n=4$ to 6 brains per group) were acquired for quantitative analysis. Laser power and settings were identical for all samples within the same experiment. The images recorded were quantified using NIH's Fiji (http://fiji.sc). Mean fluorescence intensity of region of interest was calculated from maximal intensity projection of 10 optical sections, after conversion of red, green, and blue color images into 8-bit gray scale. In the regions of interest, rectangular amyloid plaque-free areas were randomly selected $(750 \times 160 \mu \mathrm{m}$ for pyramidal layer of the CA1 region and granular cell layer of dentate gyrus, and $750 \times 250 \mu \mathrm{m}$ for the stratum radiatum) and measured. Mean values calculated for each animal were used for final statistics. Controls (WTs) were set to 1 , and data are given as means $\pm \mathrm{SEM}$ of relative fluorescence intensity.

\section{Statistical Analysis}

Statistical significance of immunofluorescence and immunoblot data was determined using unpaired Student's $t$-test. $P<0.05$ was considered significant. Numeric values are given as means \pm SEM.

Table 1 List of Antibodies Used in This Study

\begin{tabular}{llll}
\hline Antibody & Host & Epitope & Reference \\
\hline mAb7a (pGeph) & Mouse & Encompassing AA268-AA276 & 27,34 \\
& & C/L-domain, phospho-specific at AA S270 & Abcam, ab32206 \\
Anti-gephyrin antibody (Geph1) & Rabbit & Carboxy-terminus & 35 \\
Ab-175 (Geph2) & & E-domain & 36 \\
& Rabbit & AA150-AA175 & \\
\hline
\end{tabular}




\section{Results}

\section{Gephyrin Expression Decreases in Hippocampus of 12-Month-Old APPPS1 Mice}

Reduced expression of gephyrin in brains of AD patients has been reported. ${ }^{35,37}$ However, a detailed analysis of gephyrin expression in $\mathrm{AD}$ animal models is not available. First, we examined the expression of gephyrin in hippocampus homogenates of 12-month-old APPPS1 and age-matched WT mice ( $n=4$ animals per group) by immunoblot analysis, using three different anti-gephyrin antibodies. The 12-month-old mice were primarily chosen for analysis, because at this age amyloid plaques and cognitive impairments can be clearly identified in APPPS 1 mice. ${ }^{32}$ Immunoblot band intensities in protein extracts of APPPS1 mice were reduced when compared to WT mice for all three antigephyrin antibodies used (Figure 1A). The Geph1 antibody recognizing a carboxy-terminus epitope of gephyrin showed the most evident differences between the two groups (Figure 1B). To test whether this reduction of gephyrin expression is similar to changes at excitatory synapses, the protein levels of one major scaffold protein from excitatory synapses PSD95 were also determined, and were found to be reduced (Figure 1, A and B). Interestingly, longer exposure of immunoblots using antibody Geph1 revealed additional gephyrin bands with apparent molecular masses of approximately 67, 47, and $33 \mathrm{kDa}$. All three lower-molecular-weight protein bands, probably representing carboxy-terminal fragments of gephyrin, appeared reduced in hippocampus protein extracts of APPPS1 mice (Figure 1, C and D). Similar gephyrin fragments were detected in human brain tissue and correlated to $\mathrm{AD} .^{35}$

To address eventual differences in the distribution of gephyrin within hippocampus of APPPS1 and WT mice, coronal brain sections were subjected to a detailed immunohistochemical analysis. For immunolabeling, the identical three anti-gephyrin antibodies were used as for immunoblotting. Immunohistochemical analysis of methanol-fixed cryostat sections, cut from fresh frozen brains of 12-monthold APPPS1 and WT mice, revealed gephyrin immunoreactivity in the somata of neurons located in the stratum pyramidale and at the border between stratum pyramidale and stratum oriens of CA1 region of hippocampus (Figure 2, $\mathrm{A}-\mathrm{C}$ ). An intense somatic gephyrin labeling could also be seen in neurons of the granule cell layer and in the hilus of the dentate gyrus of WT mice (Figure 2, A-C). In addition, gephyrin immunoreactivity exhibited a punctate pattern, probably elicited by postsynaptic gephyrin clusters, which was more evident in the stratum radiatum (Figure 2, A-C) and most intensively detected by the Geph2 antibody
A

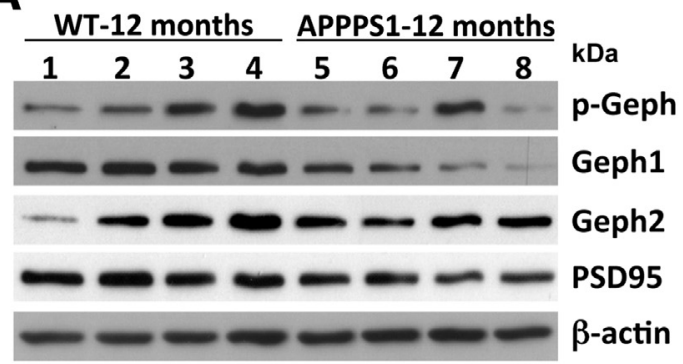

C

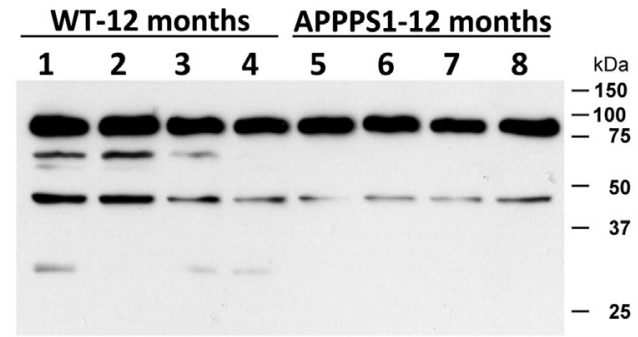

B

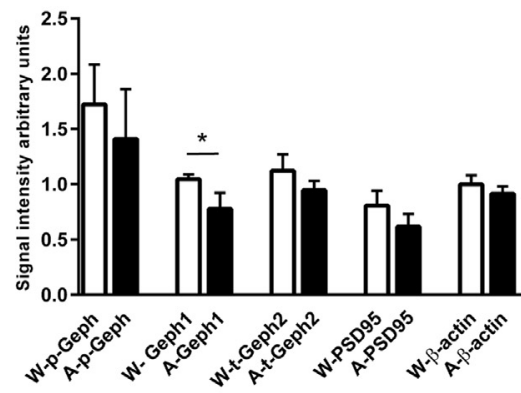

D

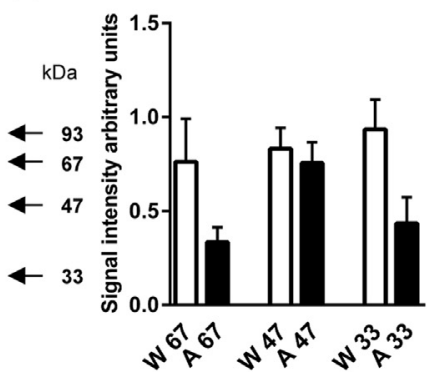

Figure 1 Gephyrin expression is reduced in hippocampus homogenates of 12-month-old APPPS1 mice. A: Representative immunoblot of hippocampus lysates obtained from 12-month-old wild-type (WT) and APPPS1 mice and probed with a phospho-specific anti-gephyrin antibody (mAb7a) (p-Geph), two pan anti-gephyrin antibodies (Geph1), and Ab-175 (Geph2), an anti-postsynaptic density protein 95 (PSD95) antibody, and a mouse anti- $\beta$-actin antibody. B: Quantification of protein band intensities shown in A. Note the significant reduction of gephyrin protein levels detected with Geph1. Band intensities were quantified with four immunoblot replicates for four mice for each condition. Student's t-test was used. C: Representative immunoblot of hippocampus lysates obtained from 12-month-old mice and probed with antibody Geph1 using longer film exposure times reveals three additional Geph1-positive bands with apparent molecular masses of 67, 47, and $33 \mathrm{kDa}$. D: Quantification of signal intensities of three to four replica membranes for the gephyrin-positive bands of $67,47$, and 33. Student's $t$-test reveals no significant differences between mean values. Data are given as means \pm SEM (B and $\mathbf{D}) . n=4$ (B). ${ }^{\star} P<0.05$ transgenic versus WT mice. 

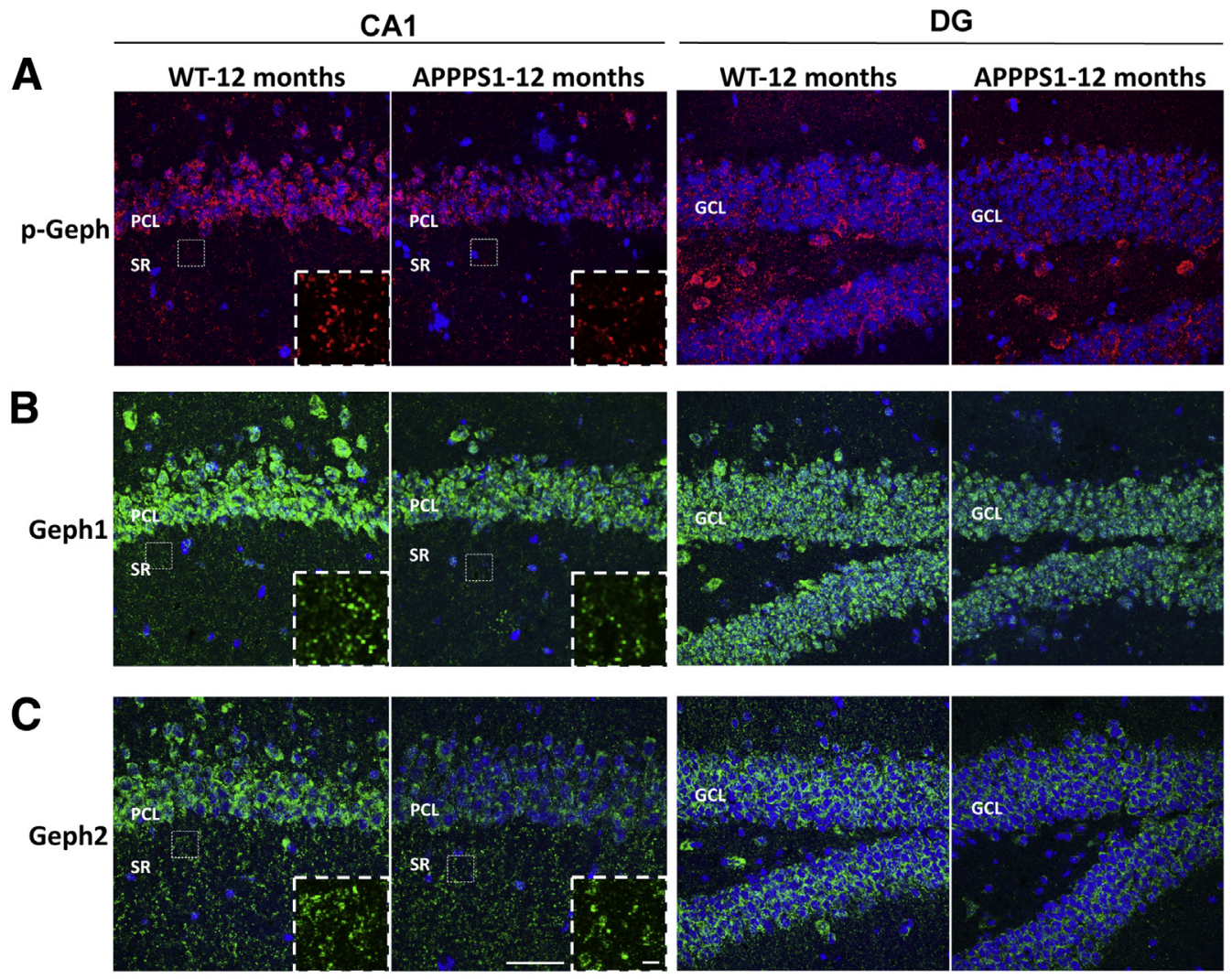

D

CA1 pyramidal cell layer

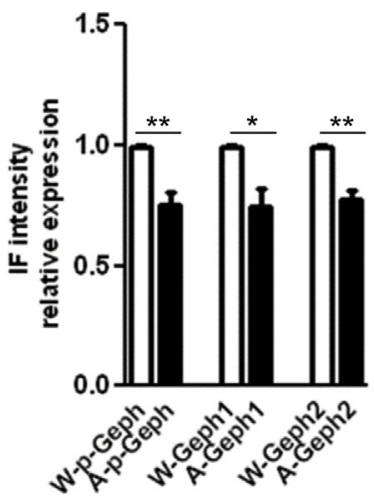

CA1 stratum radiatum

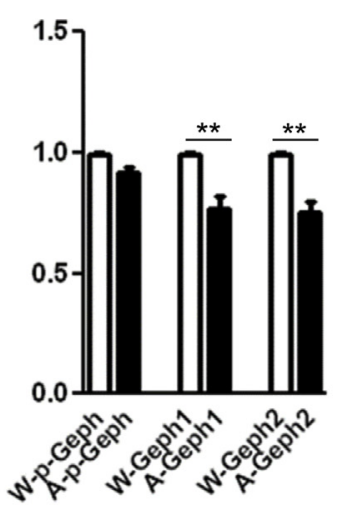

DG

granular cell layer

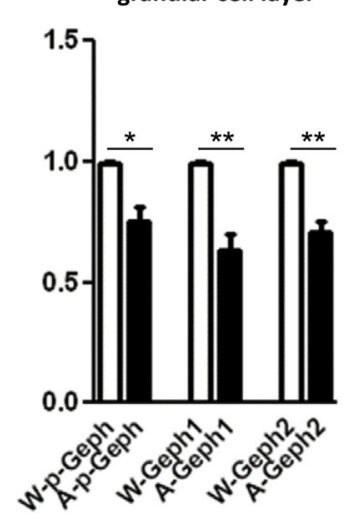

Figure 2 Reduced gephyrin immunoreactivity in hippocampus sections of 12-month-old APPPS1 mice. Decrease in gephyrin expression within the CA1 region and dentate gyrus of the hippocampus of 12-month-old APPPS1 mice as compared to wild-type mice (WT). Using three different antibodies against gephyrin, p-Geph (A), Geph1 (B), and Geph2 (C). The micrographs clearly show the significant reduction in gephyrin immunoreactivity within the pyramidal cell layer (PCL) and the adjacent stratum radiatum (SR) as well as within the granular cell layer (GCL) of dentate gyrus in the APPPS1 model. Comparing the rather intense gephyrin immunreactivity in the somata of neurons of pyramidal and granular cell layers, the decrease in the labeling intensity in the APPS1 mutant is evident. Insets show gephyrin-positive clusters of different sizes within the stratum radiatum of the CA1 region. Note the strong gephyrin staining by the Geph2 antibody within dendritic layers of hippocampus. Fresh frozen hippocampal sections; confocal images. D: Quantification of gephyrin immunoreactivity in hippocampus of WT and APPPS1 mice. Data are given as means \pm SEM (D). $n=4$ animals per group (D). ${ }^{*} P<0.05,{ }^{* *} P<0.01$ transgenic versus WT mice (Student's $t$-test). Scale bars: $50 \mu \mathrm{m}(\mathbf{A}-\mathbf{C}) ; 5 \mu \mathrm{m}$ (A-C, insets).

(internal epitope) (Figure 2C). The punctate distribution pattern of gephyrin often colocalized with the presynaptic VIAAT, providing a qualitative assessment of gephyrin distribution in hippocampus (data not shown). Labeling for gephyrin by all three antibodies revealed a consistent reduction in staining intensity in hippocampus of APPPS1 mice when compared to WT (Figure 2, A-C), but there was no evident difference in the general distribution of the immunofluorescence signal. Fluorescence intensities were examined in defined regions of the hippocampus using confocal microscopy ( $n=4$ to 6 brains per group). Gray scale values measured in the pyramidal cell layer and 
stratum radiatum of CA1 region and granular cell layer of dentate gyrus (Figure 2D) confirmed a significant reduction in mean fluorescence intensities of gephyrin in hippocampus of APPPS1 mice sustaining the immunoblot data.

\section{Gephyrin Expression Increases in Hippocampus of Young APPPS1 Mice}

To gain insight into the time course of gephyrin expression during development of $\mathrm{AD}$, we next examined APPPS1 mice with minimal or no amyloid plaques and cognitive impairment, ${ }^{32}$ and compared these to age-matched controls. Unexpectedly, immunoblot analyses of hippocampus homogenates of 3-month-old mice, a stage when amyloid plaque formation is initiated in hippocampus of APPPS1 mice, indicated that gephyrin protein levels were not reduced or similar in APPPS1 animals compared to WT, but rather significantly increased. All three anti-gephyrin antibodies provided the same results: immunoblot band intensities in protein extracts of APPPS1 mice were remarkably increased with the phospho-specific antibody mAb7a (p-Geph) and similarly with Geph1 and Geph2 (Figure 3, A and B). Interestingly, the expression of the excitatory synapse protein PSD95 was not altered, suggesting a specific increase in gephyrin expression and probably its phosphorylation in 3-month-old APPPS1 mice compared to controls (Figure 3, A and B).
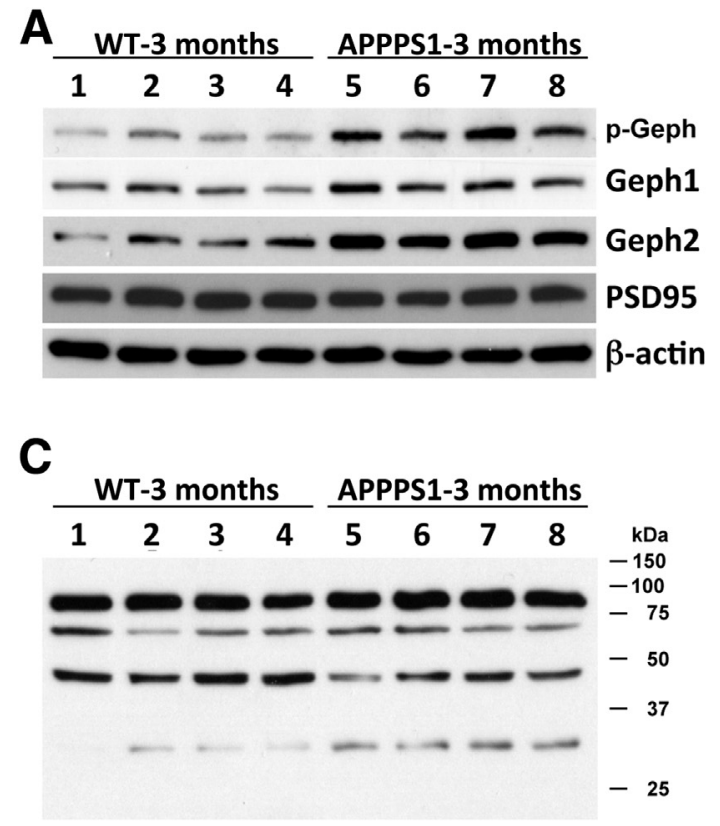

Using longer exposures of Geph1 antibody blots, an additional $47-\mathrm{kDa}$ gephyrin isoform showed lower mean values; however, the differences did not reach statistical significance. The gephyrin band of approximately $33 \mathrm{kDa}$ revealed significant increase in signal intensities in APPPS1 mice in comparison to controls, suggesting a specific alteration of proteolytic activity in APPPS1 mice (Figure 3, C and D). Analyses of hippocampus homogenates of 8-monthold animals revealed no evidence for any relevant differences in the expression of gephyrin and PSD95 between APPPS1 and WT mice (data not shown).

Next, we analyzed coronal APPPS1 brain sections of 3month-old in comparison to controls by immunohistochemistry, to verify the increase of gephyrin protein expression in more detail and to prove whether increased gephyrin expression can be demonstrated similarly in both dendritic and somatic layers of CA1 and dentate gyrus. The labeling with all three anti-gephyrin antibodies generated a similar distribution as shown in 12-month-old animals: a rather intense gephyrin immunoreactivity in the somata of neurons of pyramidal (CA1) (Figure 4, A-C) and granular cells of dentate gyrus (Figure 4, A-C). Brightly stained punctate structures, probably representing the clustered postsynaptic gephyrin, were distributed across the dendritic layers of hippocampus (insets) and were best detected by the Geph2 antibody (Figure 4C). Moreover, in comparison to

B

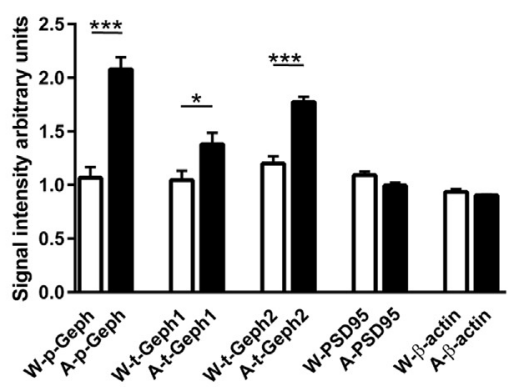

D

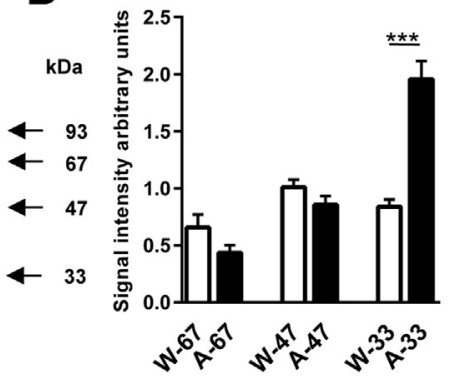

Figure 3 Gephyrin expression increases in 3-month-old APPPS1 mice hippocampus homogenates. A: Representative immunoblot of hippocampus lysates obtained from 3-month-old wild-type (WT) and APPPS1 mice and probed with the phospho-specific anti-gephyrin antibody (p-Geph), two pan anti-gephyrin antibodies (Geph1) and Ab-175 (Geph2), an anti-postsynaptic density protein 95 (PSD95) antibody, and a mouse anti- $\beta$-actin antibody. B: Quantification of protein band intensities shown in A. Note the significant increase of gephyrin protein levels detected with p-Geph, Geph1, and Geph2. Band intensities were quantified with four mice for each genotype. Student's $t$-test was used. C: Representative immunoblot of hippocampus lysates obtained from 3-month-old WT and APPPS1 mice and probed with antibody Geph1 using longer film exposure time, revealing three additional Geph1-positive bands with apparent molecular masses of 67, 47, and $33 \mathrm{kDa}$. D: Quantification of signal intensities of three to four replica membranes for the gephyrin-positive bands of 67,47 , and $33 \mathrm{kDa}$ shown in C. Note the increase of the 33-kDa band in APPPS1 protein extracts. Student's $t$-test was used. Data are given as means \pm SEM (B and D). $n=4$ (B). ${ }^{*} P<0.05,{ }^{* * *} P<0.001$ transgenic versus WT mice. 

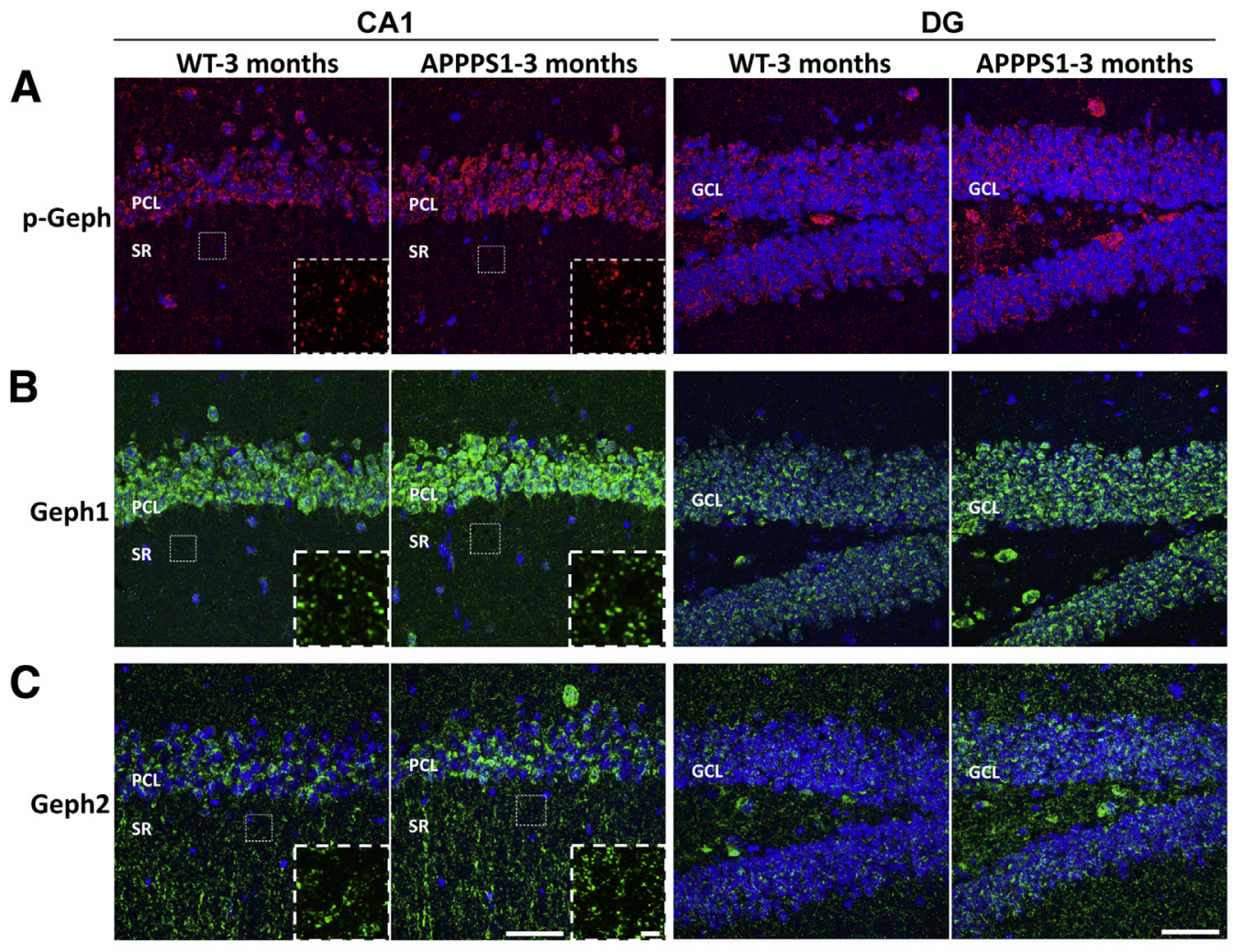

D

CA1 pyramidal cell layer
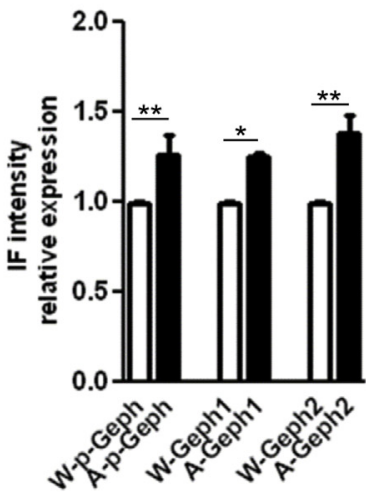

CA1 stratum radiatum
DG granular cell layer

Figure 4 Gephyrin immunoreactivity increases in hippocampus of 3-month-old APPPS1 mice. Increase in gephyrin immunoreactivity within the CA1 region and dentate gyrus of the hippocampus of 3-month-old APPPS1 mice as compared to wild-type mice (WT). Labeling with three different antibodies against gephyrin, p-Geph (A), Geph1 (B), and Geph2 (C), reveals that 3-month-old APPPS1 animals exhibit an increase in immunofluorescence intensity within the CA1 region and dentate gyrus when compared to age-matched WT mice, without any obvious differences in the general distribution pattern of the immune-signal. Fresh frozen hippocampal sections; confocal images. D: Quantification of relative fluorescence intensities in the pyramidal cell layer (PCL) and stratum radiatum (SR) of the CA1 region and granular cell layer (GCL) of the dentate gyrus (DG) confirms the increase in gephyrin immunoreactivity in APPPS1 mice as compared to WT. There were 5, 5, and 3 measurements per animal, CA1 region and DG, respectively. Data are given as means \pm SEM (D). $n=4$ to 5 animals per group (D). ${ }^{*} P<0.05,{ }^{*} P<0.01$ transgenic versus WT mice (Student's $t$-test). Scale bars: $50 \mu \mathrm{m}(\mathbf{A}-\mathbf{C}) ; 5 \mu \mathrm{m}(\mathbf{A}-\mathbf{C}$, insets).

WT, a remarkable and comparable increase of gephyrin immunoreactivity could be observed within all hippocampus layers, as shown for the CA1 region and the dentate gyrus (Figure 4, A-C). Quantification of fluorescence intensities using confocal images of different hippocampal regions (5 and 3 fields per section for CA1 and dentate gyrus, respectively; $n=4$ brains per group) provided evidence for a significant increase of gephyrin immunoreactivity in hippocampus of 3-month-old APPPS 1 mice (Figure 4D), confirming the immunoblot data.

Additional analyses of hippocampus sections from 1- and 8-month-old mice revealed a significant increase of gephyrin immunoreactivity already in 1-month-old APPPS1 mice (Supplemental Figure S1A), but corresponding to the immunoblot measurements, no relevant differences between APPPS1 and WT mice could be determined at the age of 
8 months (Supplemental Figure S1B), indicating a transitory state to late stages of $\mathrm{AD}$.

Increased Expression of $G A B A_{A} R-\gamma 2$ Subunits and VIAAT Protein in 3-Month-Old APPPS1 Mice

The noteworthy changes in gephyrin expression in APPPS1 mice of different ages point to possible age-dependent alterations of inhibitory synapses during amyloidogenesis. To clarify if the altered gephyrin expression is an isolated and specific phenomenon or other inhibitory synapse components are correspondingly affected, we studied the localization of presynaptic VIAAT and the postsynaptic $\gamma 2$-subunit of $\mathrm{GABA}_{\mathrm{A}} \mathrm{R}$, the latter crucially involved in gephyrindependent clustering of $\mathrm{GABA}_{\mathrm{A}} \mathrm{Rs} .{ }^{38}$ In agreement, we found only a slight decrease in the immunoreactivity of VIAAT in the CA1 region and dentate gyrus of 12-month-old APPPS1 mice (Figure 5, A and C) (data not shown). However, in 3-month-old APPPS1 mice the immunoreactivity of VIAAT was increased in comparison to WT mice, especially in the pyramidal layer of the CA1 region (Figure 6, A and C). The changes in $\mathrm{GABA}_{\mathrm{A}} \mathrm{R}-\gamma 2$ expression in hippocampus were found to be comparable to the alterations seen in gephyrin expression, both in 12- (Figure 5B) and 3-monthold APPPS1 (Figure 6B) mice. Accordingly, a striking decrease in $\mathrm{GABA}_{\mathrm{A}} \mathrm{R}-\gamma 2$ immunoreactivity was observed in the CA1 region as well as in the dentate gyrus (Figure 5, B and C) of 12-month-old APPPS1 mice, in contrast, to a remarkable increase in the hippocampus of 3-month-old APPPS1 mice (Figure 6B). Quantifications of fluorescence

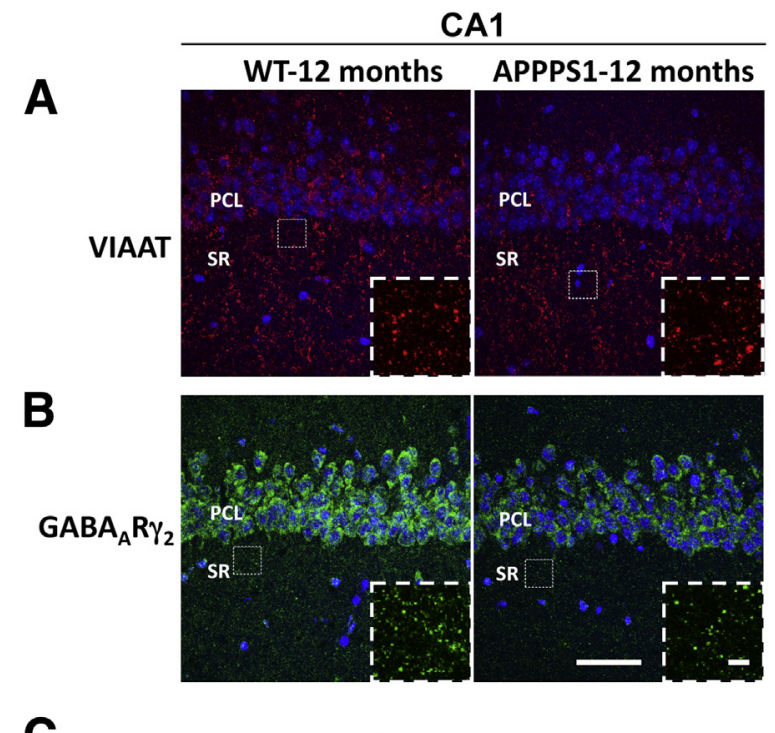

C

CA1 pyramidal cell layer

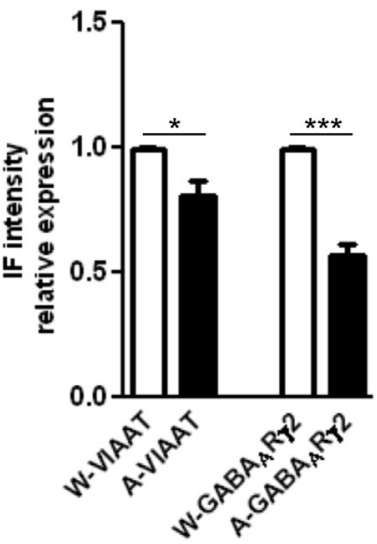

stratum radiatum

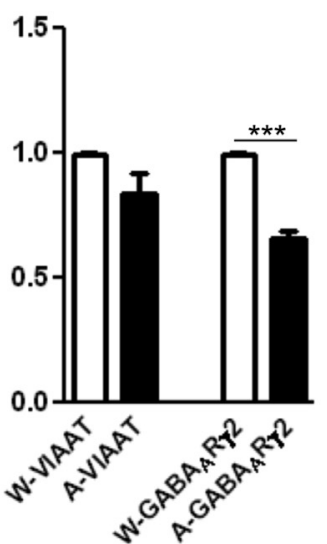

DG
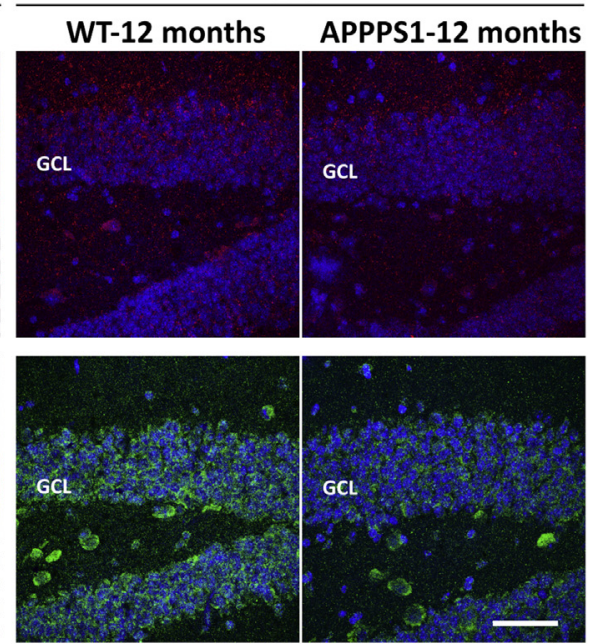

DG granular cell layer

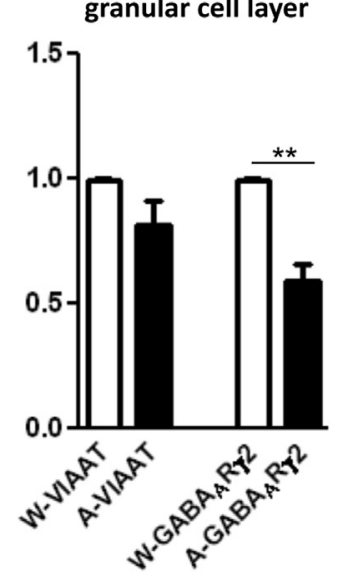

Figure 5 Decreased expression of $\mathrm{GABA}_{A} \mathrm{R} \gamma 2$ subunits in 12-month-old APPPS1 mice. Confocal microscopy reveals comparative expression levels of the presynaptic vesicular amino acid transporter (VIAAT; A) and postsynaptic $\mathrm{GABA}_{A} \mathrm{R} \gamma 2$ (B) within the hippocampus of 12-month-old wild-type (WT) and APPPS1 mice. Both the presynaptic and postsynaptic marker display a decrease in immunoreactivity within the CA1 region as well as within the granular cell layer of dentate gyrus in APPPS1 mice in comparison to WT mice. However, the reduction of GABA $A_{A} \gamma 2$ immunreactivity in APPPS1 mutant compared to WT is more evident. Insets show immunoreactive puncta in stratum radiatum (SR). Fresh frozen hippocampal sections; confocal images. C: Quantitative evaluation attests the significant reduction of $\mathrm{GABA}_{A} \mathrm{R} \gamma 2$ immunoreactivity in hippocampus of 12-month-old APPPS1 mice in comparison to WT, whereas VIAAT immunoreactivity does not change significantly. Data are given as means \pm SEM (C). $n=4$ to 5 animals per group (C). ${ }^{*} P<0.05,{ }^{* *} P<0.01$, and ${ }^{* * * P} P 0.001$ transgenic versus WT mice (Student's t-test). Scale bars: $50 \mu \mathrm{m}$ (A and B); $5 \mu \mathrm{m}$ (A and B, insets). GCL, granular cell layer; PCL, pyramidal cell layer. 


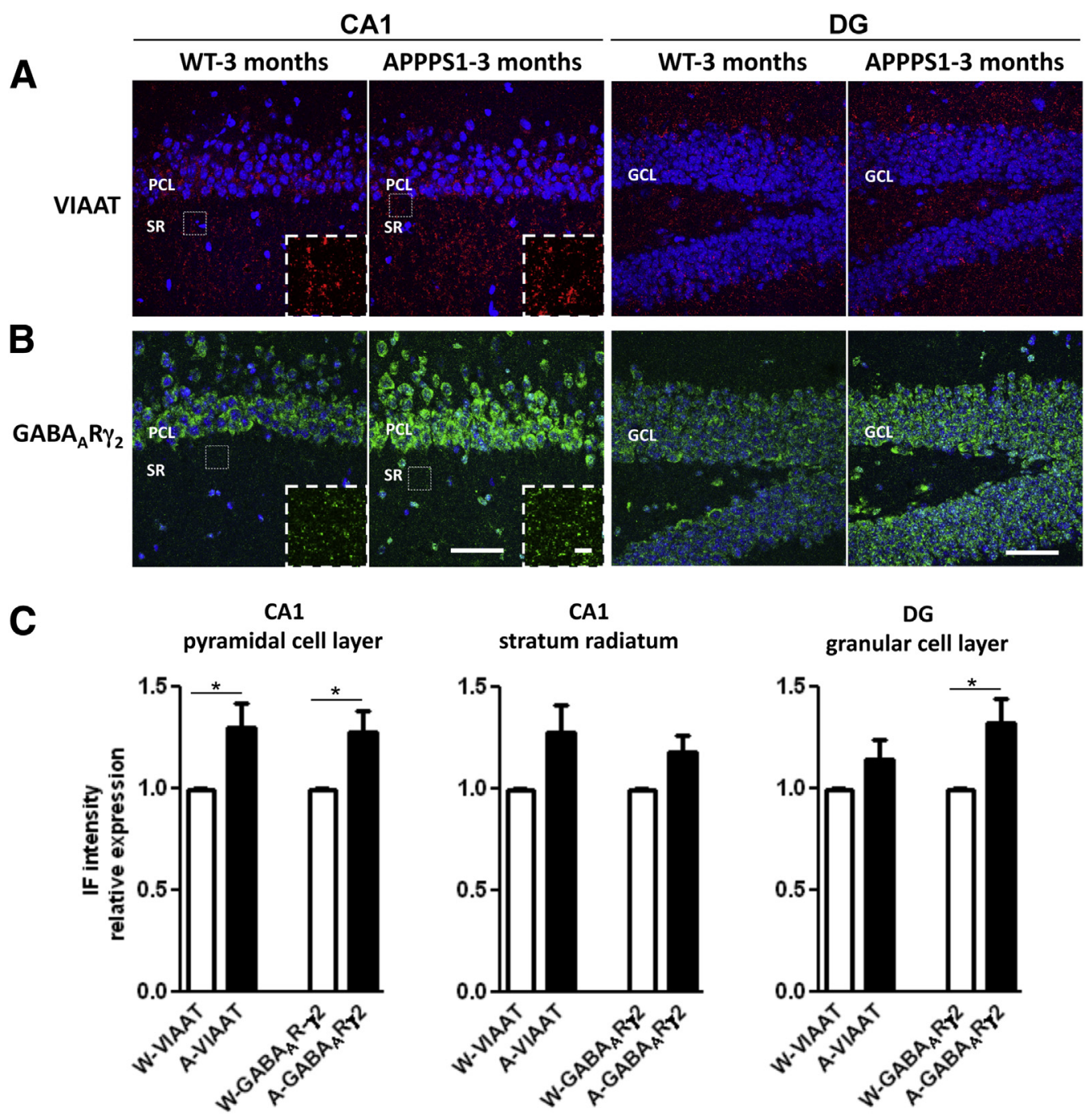

Figure 6 Increased expression of $\mathrm{GABA}_{A} \mathrm{R} \gamma 2$ subunits and vesicular amino acid transporter (VIAAT) protein in 3-month-old APPPS1 mice. Increase in

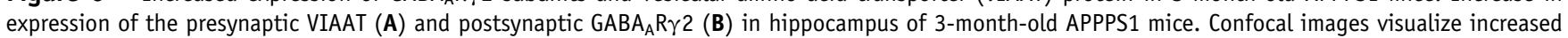
perisomatic and dendritic VIAAT and $\mathrm{GABA}_{A} \mathrm{R} \gamma 2$ immunoreactivity in the CA1 pyramidal cell layer (PCL) and stratum radiatum (SR) as well as in the granular cell layer (GCL) of dentate gyrus of APPPS1 mutants when compared to wild-type mice (WT). Insets show immunoreactive puncta in SR, probably associated with dendritic shafts. C: Quantification of fluorescence intensities document a marked increase in $\mathrm{GABA}_{A} \mathrm{R} \gamma 2$ immunoreactivity in APPPS1 mice, whereas VIAAT immunoreactivity does not increase significantly. Data are given as means \pm SEM (C). $n=4$ to 5 animals per group (C). ${ }^{*} P<0.05$ transgenic versus WT mice (Student's $t$-test). Scale bars: $50 \mu \mathrm{m}$ (A and $\mathbf{B}) ; 5 \mu \mathrm{m}$ (A and $\mathbf{B}$, insets).

intensities evidenced statistically significant differences between APPPS1 and WT mice at both 12 (Figure 5C) and 3 months (Figure $6 \mathrm{C}$ ) of age, suggesting that the altered expression rate of the $\mathrm{GABA}_{\mathrm{A}} \mathrm{Rs}$ anchoring protein gephyrin could have an important impact on the number of functional receptors and thus affect GABAergic neurotransmission in APPPS1 mice.

\section{Gephyrin Is Localized within Amyloid Plaques}

Immunoreactivity of gephyrin in confocal images was measured exclusively in amyloid plaque-free regions of hippocampus. As gephyrin accumulation in amyloid plaques of AD patients has been notified by Hales et al, ${ }^{35}$ we evaluated the gephyrin staining pattern of amyloid plaques in hippocampus of 12-month-old APPPS1 mice. Double immunolabeling of gephyrin with the W02 antibody against human $\beta$-amyloid demonstrated colocalization of gephyrinpositive punctate structures with $\mathrm{A} \beta$-positive plaques (Figure 7A and Supplemental Figure S2A). Gephyrinpositive punctate structures even colocalized with presynaptic VIAAT (Figure 7B and Supplemental Figure S2B) and postsynaptic $\mathrm{GABA}_{\mathrm{A}} \mathrm{R}-\gamma 2$ (Figure $7 \mathrm{C}$ and Supplemental Figure S2D), indicating the presence of residual synaptic components within plaques. Double labeling of gephyrin with the MAP-2 antibody demonstrated MAP-2-positive structures surrounding the gephyrin-positive plaques, but not within the plaque, indicating the lack of intact dendritic segments within amyloid aggregates. Furthermore, gephyrinpositive puncta colocalized with the MAP-2-positive 

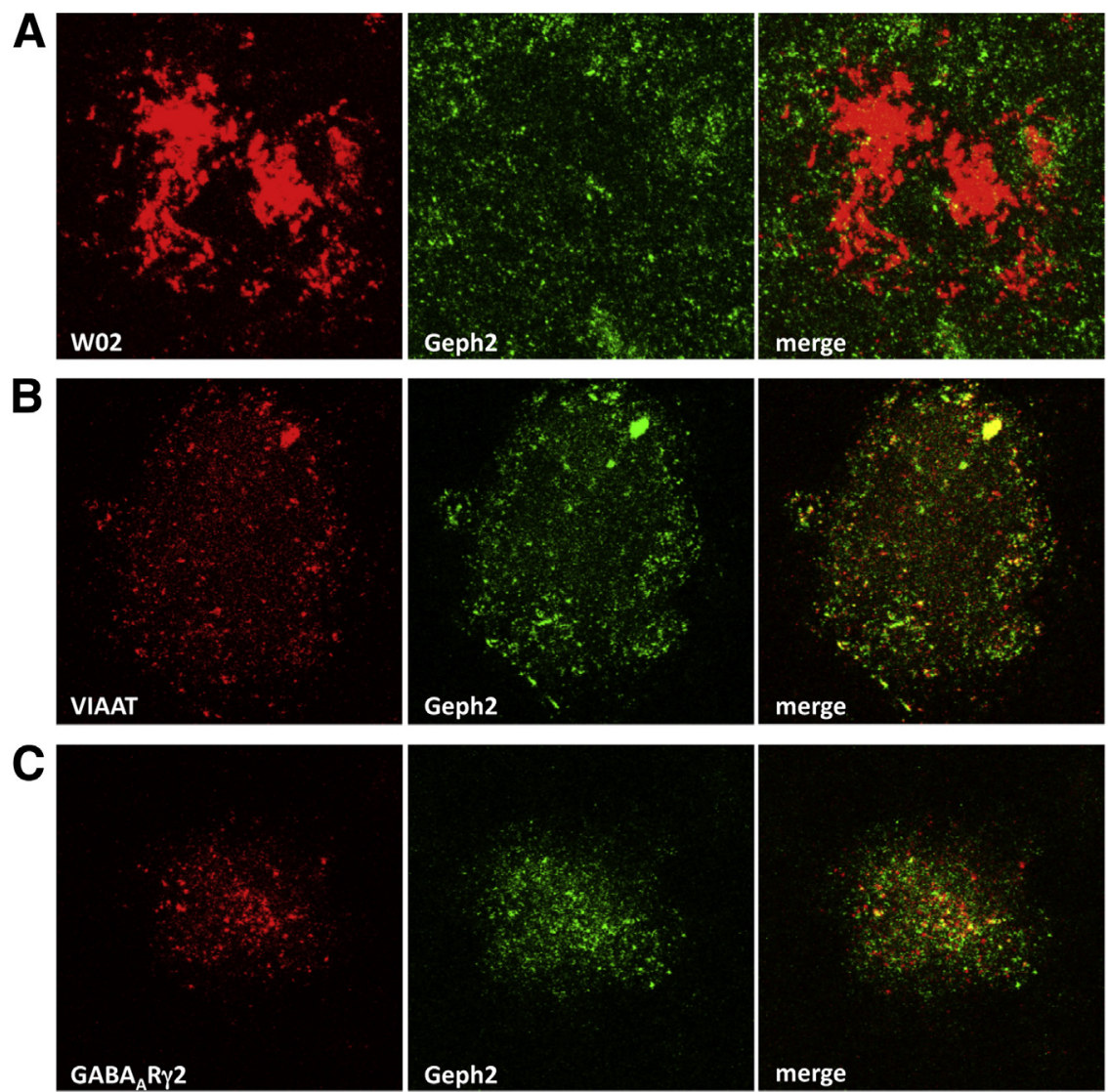

D

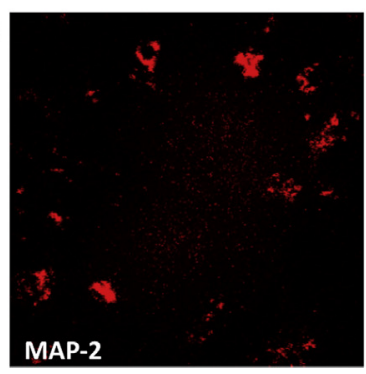

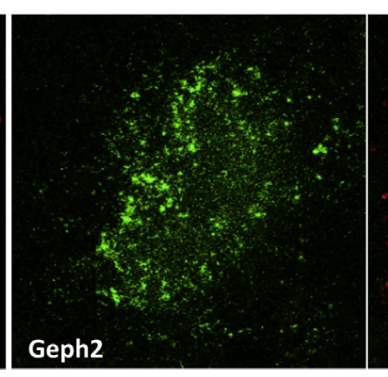

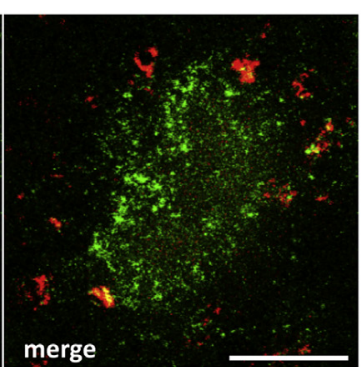

Figure 7 Gephyrin immunoreactivity in amyloid plaques. Intense synaptic and extrasynaptic gephyrin immunoreactivity marks the amyloid plaques of APPPS1 mice. A: Double immunfluorescence labeling for human $\beta$-amyloid (W02, red) and gephyrin (Geph2, green) in hippocampus of 12-month-old APPPS1 mice shows numerous gephyrin-positive puncta in the area of amyloid plaques. Most of gephyrin-positive puncta (Geph2, green) colocalize with the presynaptic vesicular amino acid transporter (VIAAT; red), especially in the peripheral region of the plaque (B), and with postsynaptic $G_{A B A} R \gamma 2$ (red) (C). Solitary gephyrin-positive puncta (green) can also be observed. D: Gephyrin puncta within amyloid plaques are surrounded by microtuble-associated protein 2 (MAP-2)-positive structures. The localization of gephyrin-positive inhibitory synapses (green) on these MAP-2-positive structures (red) is indicated by yellow puncta in the merged image. Fresh frozen sections; confocal images. Scale bar $=5 \mu \mathrm{m}(\mathbf{A}-\mathbf{D})$. structures at the periphery of plaque areas (Figure 7D and Supplemental Figure S2C).

\section{Discussion}

Our time course analysis (1, 3, 8, and 12 months) of the expression of gephyrin in the APPPS 1 model provides novel information concerning changes of inhibitory synaptic proteins in AD. First, our data confirm and extend earlier reports on mouse models and human $\mathrm{AD}$ brains that gephyrin and inhibitory synapses are reduced in advanced stages of AD. ${ }^{9,37,39}$ By immunohistochemistry, we have shown the overall reduction of gephyrin in CA1 and dentate gyrus regions of the hippocampus devoid of amyloid plaques, but an evident difference in the general distribution pattern of gephyrin immune signal could not be detected.
Second, our immunoblot analysis of hippocampus homogenates demonstrated an age-dependent specific alteration of stable carboxy-terminal fragments of gephyrin supporting the findings raised in human AD brains. ${ }^{35}$ Finally, we provide, for the first time, evidence for specific structural alterations - an increase in gephyrin and $\gamma 2-\mathrm{GABA}_{\mathrm{A}}$ receptor immunoreactivity as well as elevated levels in immunoreactivity of inhibitory presynaptic marker protein VIAAT - in hippocampus of young APPPS 1 mice (1 and 3 months), corresponding to early presymptomatic stages of $\mathrm{AD}$.

Specific soluble $A \beta$ oligomers and hyperphosphorylated tau have been shown to initiate structural and functional alterations of excitatory spiny synapses in hippocampus and various other brain regions, and it is believed that these processes are one major cellular and molecular basis for onset of $\mathrm{AD}$ pathology. ${ }^{40,41}$ For a long time, GABAergic 
neurotransmission, the major inhibitory system in the brain, has been considered to be well preserved in $\mathrm{AD} .^{11,42}$ Recently, increasing evidence indicates that changes in GABAergic neurotransmission may also be involved in the physiopathology of $\mathrm{AD}$, but data concerning structural alterations of inhibitory synapses in AD pathology are largely missing. Treatment with dihydromyricetin, a positive allosteric modulator of $\mathrm{GABA}_{\mathrm{A}} \mathrm{Rs}$, has been shown to ameliorate behavioral deficits and reverses neuropathology in 22-month-old transgenic mice (TG2576 and TG-SwDI). The observed effects were attributed particularly to reduced $A \beta$ concentrations as well as to restored gephyrin levels, and thus to restored GABAergic transmission and synaptic function. ${ }^{39}$ In vitro, $\mathrm{GABA}_{\mathrm{A}}$ receptor agonists protected cultured neurons against the neurotoxicity of A.$^{43,44}$ However, controversial in vivo data demonstrated that treatment with picrotoxin, a $\mathrm{GABA}_{\mathrm{A}} \mathrm{R}$ antagonist, improves the cognitive functions of adult APPPS 1 mice. ${ }^{45}$

In postmortem $\mathrm{AD}$ brains, reduced frontal, temporal, and parietal GABA concentrations and benzodiazepine binding sites (ie, $\left.\mathrm{GABA}_{\mathrm{A}} \mathrm{Rs}\right)^{10}$ and a decrease in $\mathrm{GABA}_{\mathrm{A}} \mathrm{R}$ mediated $\mathrm{Cl}^{-}$current of cortical membranes ${ }^{12}$ were observed. An increased insoluble gephyrin fragment of $37 \mathrm{kDa}$ was also detected, suggesting altered solubility of gephyrin in $\mathrm{AD} .{ }^{35}$ Interestingly, Costa et $\mathrm{al}^{46}$ reported that in vitro brain ischemia down-regulated full-length gephyrin and increased simultaneously a calpain (a calcium-dependent cysteine protease) cleavage product affecting synaptic clustering of $\mathrm{GABA}_{\mathrm{A}}$ Rs. Thus, our findings, showing a decrease in gephyrin expression and of $\gamma 2-\mathrm{GABA}_{\mathrm{A}} \mathrm{R}$-subunit in hippocampus of adult APPPS1 mice, are in agreement with earlier observations and support the concept that a decrease of inhibitory GABAergic synapses and specifically of the scaffold protein gephyrin might be a consistent parameter in the pathogenesis of AD.

Recently, attention has shifted to earlier nonsymptomatic stages of $\mathrm{AD}$, to identify the basic cause of early structural and functional alterations, which might allow earlier diagnosis of the disease process and hopefully medical intervention. One interesting result of several functional magnetic resonance imaging studies in recent years was the observation that the decrease in neuronal activity associated with late stages of $\mathrm{AD}$ is preceded by a stage of neuronal hyperactivity. ${ }^{47,48}$ On the molecular level, it was shown that in Braak stages I and II, just before plaque formation, the expression of genes involved in synaptic functions was increased, whereas expression of synaptic activity-dependent genes was reduced by the onset of pathological and cognitive symptoms. ${ }^{49}$ The detected genes included different $\mathrm{GABA}_{\mathrm{A}} \mathrm{R}$ subunits and the glycine receptor $\beta$ subunit, essentially involved in anchoring the inhibitory glycine receptor to gephyrin at inhibitory synapses. ${ }^{50}$ Our results demonstrating increased levels of gephyrin, $\mathrm{GABA}_{\mathrm{A}} \mathrm{R} \gamma 2$ subunits, and presynaptic VIAAT in CA1 and dentate gyrus of 1- and 3-month-old APPPS1 mice not only correlate with these findings, but extend these earlier RNA expression data on protein and structural anatomical level. In addition, the concordance between data in human and in APPPS1 mouse indicates the similarities and suitability of this transgenic model for further studies on this topic.

Complementary to previous analyses on the expression of gephyrin in $\mathrm{AD}$ models or postmortem human brain, ${ }^{35,37,39}$ our immunohistochemical methods on fresh frozen brain sections allowed us to study the distribution pattern of gephyrin in different areas of hippocampus. Because of the fact that global neuronal loss is not observed in the APPPS1 mice, even in the granular cell layer of the dentate gyrus first at older ages (eg, 17 months), ${ }^{33}$ the found changes in protein expression cannot be attributed to changes in cell number. The consistency of our data is supported by the use of three different antibodies against gephyrin. In addition to the two pan-gephyrin antibodies (Geph1 and Geph2), we used the mAb7a (pGeph) antibody to analyze the expression of phospho-gephyrin in hippocampus of APPPS1 mice, because phosphorylation has been shown to be involved in regulation of $\mathrm{GABA}_{\mathrm{A}} \mathrm{R}$ clustering. ${ }^{25,28} \mathrm{Geph} 1$ antibody revealed stronger staining in the pyramidal cell layer compared to SR than the Geph2 antibody. Immunoblot analysis has shown that the Geph1 antibody detects the full length gephyrin and in addition carboxy-terminal gephyrin isoforms of 67,47 , and $33 \mathrm{kDa}$. Thus, the immunofluorescence data suggest that these gephyrin polypeptides are localized preferentially in the somatic and not in the distal dendritic compartment. In the stratum radiatum of CA1, weaker immunosignals were observed by pGeph antibody, compared especially to the Geph 2 antibody. These findings are consistent with earlier in vitro studies with cultured hippocampal neurons, indicating higher relative phosphorylation of gephyrin in the somatic than in the distal dendritic compartment. ${ }^{28}$

Taken together, all three anti-gephyrin antibodies demonstrate a significant increase of gephyrin protein level and phosphorylation in the stratum pyramidale of CA1 region and the granular cell layer of dentate gyrus of 1- and 3-month-old APPPS1 mice compared to controls. In addition, $\gamma 2-G_{A B A} R$ staining, as well as the level of the inhibitory presynaptic VIAAT, was increased in these brain regions of APPPS1 mice. Thus, our data collectively suggest an increased somatodendritic inhibitory input in hippocampus of young APPPS1 mice.

Both in vitro and in vivo studies indicate a putative synaptogenic function of full-length APP. ${ }^{51,52}$ Lee et $\mathrm{al}^{52}$ reported increased spine number in young APP transgenic mice (Tg2567), and this was accompanied by an increase in the numbers of excitatory synapses, as revealed by the synaptic marker PSD95. In older animals, APP transgenes displayed significant spine loss, likely because of agedependent accumulation of $A \beta$. However, published data regarding the role of APP in spine and synapse formation are controversial. ${ }^{53}$ Furthermore, for excitatory synapses, it was proposed that the increased expression of synaptic proteins and increased activity observed in presymptomatic 
stages of $\mathrm{AD}$ might be a compensatory response to increased $A \beta$ levels, which would cause reduced synaptic efficacies. ${ }^{49}$ Whether APP and/or A $\beta$ might affect directly the structure and function of inhibitory synapses as well is presently unknown.

The level of $A \beta$ is known to be dependent on the level of excitatory glutamatergic synapse activity ${ }^{54}$ and is thought to be part of a negative feedback loop preventing neuronal hyperexcitability. ${ }^{55}$ More precisely, low (picomolar) levels of $\mathrm{A} \beta$ were shown to potentiate excitatory synapse activity, whereas higher $A \beta$ concentrations (nanomolar) would be inhibitory to neuronal firing because of reduction of different glutamate receptors by receptor internalization, and persistent high $A \beta$ concentrations would cause neurotoxicity. ${ }^{56,57}$ The increase of inhibitory input in young APPPS1 mice described herein fits functionally in this scheme as an increasing concentration of $\mathrm{A} \beta$ might induce a strong somatodendritic inhibition to balance neuronal network activity. In this context, Palop et $\mathrm{al}^{58}$ reported a compensatory remodeling of inhibitory mechanisms in hippocampal circuits to hAPP/A $\beta$-induced aberrant excitatory neuronal activity. Thus, it is tempting to speculate that the increase of inhibitory input in young APPPS 1 mice is a compensatory and supportive mechanism, to protect hippocampal neurons against $\mathrm{A} \beta$-induced neurotoxicity because of deregulated glutamate receptors. ${ }^{44}$

In conclusion, an increasing $A \beta$ concentration gradient over time might deregulate intrinsic homeostatic circuit mechanisms, resulting in functional impairment of neurotransmission in the brain because of the loss of protective action of GABAergic synapses during AD progression.

\section{Supplemental Data}

Supplemental material for this article can be found at http://dx.doi.org/10.1016/j.ajpath.2016.05.013.

\section{References}

1. Alzheimer's Association: 2014 Alzheimer's disease facts and figures. Alzheimers Dement 2014, 10:e47-e92

2. Braak H, de Vos RA, Jansen EN, Bratzke H, Braak E: Neuropathological hallmarks of Alzheimer's and Parkinson's diseases. Prog Brain Res 1998, 117:267-285

3. Tanzi RE, Bertram L: Twenty years of the Alzheimer's disease amyloid hypothesis: a genetic perspective. Cell 2005, 120:545-555

4. Hsia AY, Masliah E, McConlogue L, Yu GQ, Tatsuno G, Hu K, Kholodenko D, Malenka RC, Nicoll RA, Mucke L: Plaque-independent disruption of neural circuits in Alzheimer's disease mouse models. Proc Natl Acad Sci U S A 1999, 96:3228-3233

5. Mucke L, Selkoe DJ: Neurotoxicity of amyloid $\beta$-protein: synaptic and network dysfunction. Cold Spring Harb Perspect Med 2012, 2: a006338

6. Shankar GM, Bloodgood BL, Townsend M, Walsh DM, Selkoe DJ, Sabatini BL: Natural oligomers of the Alzheimer amyloid-beta protein induce reversible synapse loss by modulating an NMDA-type glutamate receptor-dependent signaling pathway. J Neurosci 2007, $27: 2866-2875$
7. Viola KL, Klein WL: Amyloid $\beta$ oligomers in Alzheimer's disease pathogenesis, treatment, and diagnosis. Acta Neuropathol 2015, 129 : 183-206

8. Tu S, Okamoto S, Lipton SA, Xu H: Oligomeric A $\beta$-induced synaptic dysfunction in Alzheimer's disease. Mol Neurodegener 2014, 9:48

9. Chu DC, Penney JB Jr, Young AB: Quantitative autoradiography of hippocampal GABAB and GABAA receptor changes in Alzheimer's disease. Neurosci Lett 1987, 82:246-252

10. Lanctôt KL, Herrmann $N$, Mazzotta $P$, Khan LR, Ingber $N$ : GABAergic function in Alzheimer's disease: evidence for dysfunction and potential as a therapeutic target for the treatment of behavioural and psychological symptoms of dementia. Can J Psychiatry 2004, 49:439-453

11. Rissman RA, Mobley WC: Implications for treatment: GABAA receptors in aging, Down syndrome and Alzheimer's disease. J Neurochem 2011, 117:613-622

12. Limon A, Reyes-Ruiz JM, Miledi R: Loss of functional GABA(A) receptors in the Alzheimer diseased brain. Proc Natl Acad Sci U S A 2012, 109:10071-10076

13. Bateup HS, Johnson CA, Denefrio CL, Saulnier JL, Kornacker K, Sabatini BL: Excitatory/inhibitory synaptic imbalance leads to hippocampal hyperexcitability in mouse models of tuberous sclerosis. Neuron 2013, 78:510-522

14. Nakazawa K, Zsiros V, Jiang Z, Nakao K, Kolata S, Zhang S, Belforte JE: GABAergic interneuron origin of schizophrenia pathophysiology. Neuropharmacology 2012, 62:1574-1583

15. Letzkus JJ, Wolff SB, Meyer EM, Tovote P, Courtin J, Herry C, Lüthi A: A disinhibitory microcircuit for associative fear learning in the auditory cortex. Nature 2011, 480:331-335

16. Feng G, Tintrup H, Kirsch J, Nichol MC, Kuhse J, Betz H, Sanes JR: Dual requirement for gephyrin in glycine receptor clustering and molybdoenzyme activity. Science 1998, 282:1321-1324

17. Kneussel M, Brandstatter JH, Laube B, Stahl S, Muller U, Betz H: Loss of postsynaptic GABA(A) receptor clustering in gephyrindeficient mice. J Neurosci 1999, 19:9289-9297

18. O'Sullivan GA, Jedlicka P, Chen HX, Kalbouneh H, Ippolito A, Deller T, Nawrotzki RA, Kuhse J, Kalaidzidis YL, Kirsch J, Schwarzacher SW, Betz H: Forebrain-specific loss of synaptic GABAA receptors results in altered neuronal excitability and synaptic plasticity in mice. Mol Cell Neurosci 2016, 72:101-113

19. Tyagarajan SK, Fritschy JM: Gephyrin: a master regulator of neuronal function? Nat Rev Neurosci 2014, 15:141-156

20. Dresbach T, Nawrotzki R, Kremer T, Schumacher S, Quinones D, Kluska M, Kuhse J, Kirsch J: Molecular architecture of glycinergic synapses. Histochem Cell Biol 2008, 130:617-633

21. Feng W, Zhang M: Organization and dynamics of PDZ-domainrelated supramodules in the postsynaptic density. Nat Rev Neurosci 2009, 10:87-89

22. Kirsch J, Langosch D, Prior P, Littauer UZ, Schmitt B, Betz H: The 93-kDa glycine receptor-associated protein binds to tubulin. J Biol Chem 1991, 266:22242-22245

23. Fuhrmann JC, Kins S, Rostaing P, El Far O, Kirsch J, Sheng M, Triller A, Betz H, Kneussel M: Gephyrin interacts with Dynein light chains 1 and 2, components of motor protein complexes. J Neurosci 2002, 22:5393-5402

24. Maas C, Belgardt D, Lee HK, Heisler FF, Lappe-Siefke C, Magiera MM, van Dijk J, Hausrat TJ, Janke C, Kneussel M: Synaptic activation modifies microtubules underlying transport of postsynaptic cargo. Proc Natl Acad Sci U S A 2009, 106:8731-8736

25. Tyagarajan SK, Ghosh H, Yévenes GE, Nikonenko I, Ebeling C, Schwerdel C, Sidler C, Zeilhofer HU, Gerrits B, Müller D, Fritschy JM: Regulation of GABAergic synapse formation and plasticity by GSK3beta-dependent phosphorylation of gephyrin. Proc Natl Acad Sci U S A 2010, 108:379-384

26. Tyagarajan SK, Ghosh H, Yevenes GE, Imanishi SY, Zeilhofer HU, Gerrits B, Fritschy JM: ERK and GSK3beta regulate gephyrin 
postsynaptic aggregation and GABAergic synaptic function in a calpain-dependent mechanism. J Biol Chem 2013, 288:9634-9647

27. Kuhse J, Kalbouneh H, Schlicksupp A, Mükusch S, Nawrotzki R, Kirsch J: Phosphorylation of gephyrin in hippocampal neurons by cyclin-dependent kinase CDK5 at Ser-270 is dependent on collybistin. J Biol Chem 2012, 287:30952-30966

28. Kalbouneh H, Schlicksupp A, Kirsch J, Kuhse J: Cyclin-dependent kinase 5 is involved in the phosphorylation of gephyrin and clustering of $\mathrm{GABA}_{\mathrm{A}}$ receptors at inhibitory synapses of hippocampal neurons. PLoS One 2014, 9:e104256

29. Liu SL, Wang C, Jiang T, Tan L, Xing A, Yu JT: The role of Cdk5 in Alzheimer's disease. Mol Neurobiol 2016, 53:4328-4342

30. Morris M, Maeda S, Vossel K, Mucke L: The many faces of tau. Neuron 2011, 70:410-426

31. Gengler S, Hamilton A, Hölscher C: Synaptic plasticity in the hippocampus of a APP/PS1 mouse model of Alzheimer's disease is impaired in old but not young mice. PLoS One 2010, 5:e9764

32. Radde R, Bolmont T, Kaeser SA, Coomaraswamy J, Lindau D, Stoltze L, Calhoun ME, Jäggi F, Wolburg H, Gengler S, Haass C, Ghetti B, Czech C, Hölscher C, Mathews PM, Jucker M: Abeta42driven cerebral amyloidosis in transgenic mice reveals early and robust pathology. EMBO Rep 2006, 7:940-946

33. Rupp NJ, Wegenast-Braun BM, Radde R, Calhoun ME, Jucker M: Early onset amyloid lesions lead to severe neuritic abnormalities and local, but not global neuron loss in APPPS1 transgenic mice. Neurobiol Aging 2011, 32:2324e1-2324e6

34. Pfeiffer F, Simler R, Grenningloh G, Betz H: Monoclonal antibodies and peptide mapping reveal structural similarities between the subunits of the glycine receptor of rat spinal cord. Proc Natl Acad Sci U S A 1984, 81:7224-7227

35. Hales CM, Rees H, Seyfried NT, Dammer EB, Duong DM, Gearing M, Montine TJ, Troncoso JC, Thambisetty M, Levey AI, Lah JJ, Wingo TS: Abnormal gephyrin immunoreactivity associated with Alzheimer disease pathologic changes. J Neuropathol Exp Neurol 2013, 72:1009-1015

36. Nawrotzki R, Islinger M, Vogel I, Völkl A, Kirsch J: Expression and subcellular distribution of gephyrin in non-neuronal tissues and cells. Histochem Cell Biol 2012, 137:471-482

37. Agarwal S, Tannenberg RK, Dodd PR: Reduced expression of the inhibitory synapse scaffolding protein gephyrin in Alzheimer's disease. J Alzheimers Dis 2008, 14:313-321

38. Schweizer C, Balsiger S, Bluethmann H, Mansuy IM, Fritschy JM, Mohler H, Lüscher B: The gamma 2 subunit of GABA(A) receptors is required for maintenance of receptors at mature synapses. Mol Cell Neurosci 2003, 24:442-450

39. Liang J, López-Valdés HE, Martínez-Coria H, Lindemeyer AK, Shen Y, Shao XM, Olsen RW: Dihydromyricetin ameliorates behavioral deficits and reverses neuropathology of transgenic mouse models of Alzheimer's disease. Neurochem Res 2014, 39:1171-1181

40. Arendt T: Synaptic degeneration in Alzheimer's disease. Acta Neuropathol 2009, 118:167-179

41. Palop JJ, Mucke L: Amyloid-beta-induced neuronal dysfunction in Alzheimer's disease: from synapses toward neural networks. Nat Neurosci 2010, 13:812-818

42. Mitew S, Kirkcaldie MT, Dickson TC, Vickers JC: Altered synapses and gliotransmission in Alzheimer's disease and AD model mice. Neurobiol Aging 2013, 34:2341-2351

43. Louzada PR, Paula-Lima AC, Mendonca-Silva DL, Noël F, De Mello FG, Ferreira ST: Taurine prevents the neurotoxicity of beta-amyloid and glutamate receptor agonists: activation of GABA receptors and possible implications for Alzheimer's disease and other neurological disorders. FASEB J 2004, 18:511-558

44. Paula-Lima AC, Brito-Moreira J, Ferreira ST: Deregulation of excitatory neurotransmission underlying synapse failure in Alzheimer's disease. J Neurochem 2013, 126:191-202

45. Yoshiike Y, Kimura T, Yamashita S, Furudate H, Mizoroki T, Murayama M, Takashima A: GABA(A) receptor-mediated acceleration of aging-associated memory decline in APP/PS1 mice and its pharmacological treatment by picrotoxin. PLoS One 2008, 3: e3029

46. Costa JT, Mele M, Baptista MS, Gomes JR, Ruscher K, Nobre RJ, de Almeida LP, Wieloch T, Duarte CB: Gephyrin cleavage in in vitro brain ischemia decreases GABAA receptor clustering and contributes to neuronal death. Mol Neurobiol 2016, 53:3513-3527

47. Hämäläinen A, Pihlajamäki M, Tanila H, Hänninen T, Niskanen E, Tervo S, Karjalainen PA, Vanninen RL, Soininen H: Increased fMRI responses during encoding in mild cognitive impairment. Neurobiol Aging 2007, 28:1889-1903

48. Pihlajamäki M, Jauhiainen AM, Soininen H: Structural and functional MRI in mild cognitive impairment. Curr Alzheimer Res 2009, 6: 179-185

49. Bossers K, Wirz KTS, Meerhoff GF, Essing AHW, van Dongen JW, Houba P, Kruse CG, Verhaagen J, Swaab DF: Concerted changes in transcripts in the prefrontal cortex precede neuropathology in Alzheimer's disease. Brain J Neurol 2010, 133: 3699-3723

50. Meyer G, Kirsch J, Betz H, Langosch D: Identification of a gephyrin binding motif on the glycine receptor beta subunit. Neuron 1995, 15: $563-572$

51. Baumkötter F, Schmidt N, Vargas C, Schilling S, Weber R, Wagner K, Fiedler S, Klug W, Radzimanowski J, Nickolaus S, Keller S, Eggert S, Wild K, Kins S: Amyloid precursor protein dimerization and synaptogenic function depend on copper binding to the growth factor-like domain. J Neurosci 2014, 34:11159-11167

52. Lee KJ, Moussa CE, Lee Y, Sung Y, Howell BW, Turner RS, Pak DT, Hoe HS: Beta amyloid-independent role of amyloid precursor protein in generation and maintenance of dendritic spines. Neuroscience 2010, 169:344-356

53. Jung CK, Herms J: Role of APP for dendritic spine formation and stability. Exp Brain Res 2012, 217:463-470

54. Cirrito JR, Yamada KA, Finn MB, Sloviter RS, Bales KR, May PC, Schoepp DD, Paul SM, Mennerick S, Holtzman DM: Synaptic activity regulates interstitial fluid amyloid-beta levels in vivo. Neuron 2005, 48:913-922

55. Kamenetz F, Tomita T, Hsieh H, Seabrook G, Borchelt D, Iwatsubo T, Sisodia S, Malinow R: APP processing and synaptic function. Neuron 2003, 37:925-937

56. Puzzo D, Arancio O: Fibrillar beta-amyloid impairs the late phase of long term potentiation. Curr Alzheimer Res 2006, 3:179-183

57. Puzzo D, Privitera L, Fa M, Staniszewski A, Hashimoto G, Aziz F, Sakurai M, Ribe EM, Troy CM, Mercken M, Jung SS, Palmeri A, Arancio O: Endogenous amyloid-beta is necessary for hippocampal synaptic plasticity and memory. Ann Neurol 2011, 69:819-830

58. Palop JJ, Chin J, Roberson ED, Wang J, Thwin MT, Bien-Ly N, Yoo J, Ho KO, Yu GQ, Kreitzer A, Finkbeiner S, Noebels JL, Mucke L: Aberrant excitatory neuronal activity and compensatory remodeling of inhibitory hippocampal circuits in mouse models of Alzheimer's disease. Neuron 2007, 55:697-711 